\title{
Pesticide residues in strawberry fruits cultivated under integrated pest management and conventional systems in Cundinamarca (Colombia)
}

\section{Residuos de plaguicidas en frutos de fresa cultivados en sistemas de manejo integrado de plagas y convencionales en Cundinamarca (Colombia)}

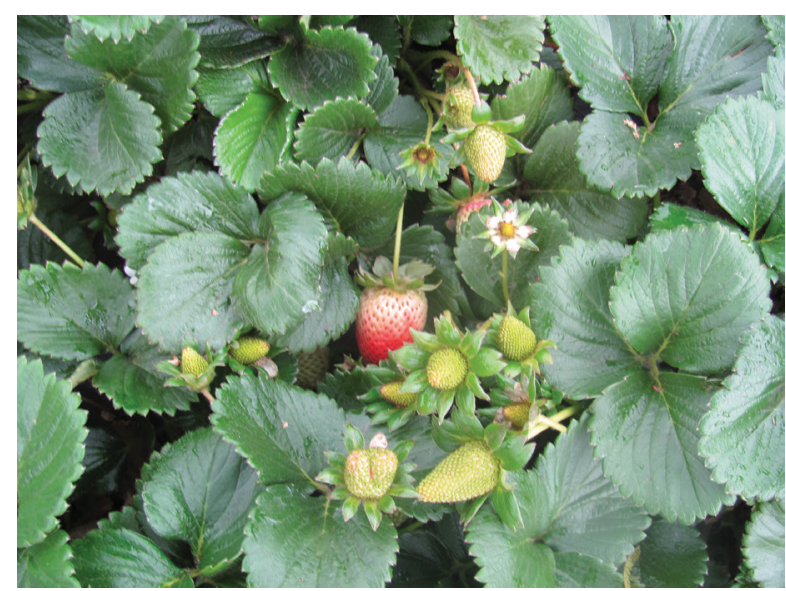

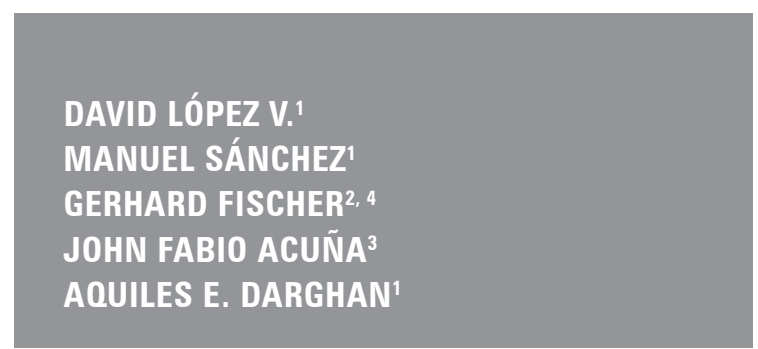

Strawberry production based on integrated pest management in Sibate (Cundinamarca, Colombia).

Photo: G. Fischer

\begin{abstract}
Because of the high susceptibility in strawberry fruits to attacks from pests and diseases, a large amount of pesticides is applied during the crop cycle and harvest period. The improper use of these substances can generate residues in agricultural products that pose a risk to human health. The objective of this study was to determine and compare pesticide residues in strawberry fruits from two different production systems distributed in the main producing areas of the Cundinamarca Department (Colombia). Eight samples of strawberry crops were collected in four producer municipalities (Guasca, Facatativa, Mosquera and Sibate) to compare different systems (conventional production vs. production based on Integrated Pest Management, IPM). Samples with a concentration of 394 molecules were examined using liquid and gas spectrometry. Fischer's exact test was used to determine the association between the pesticide type and residue level in the fruits, with more insecticide samples that exceeded the permitted threshold than when using fungicides. Twenty-two different molecules were detected in the analyzed samples, with 37 detection events, of which eight were reported in the IPM production systems and 29 in the conventional producers. The results revealed that nine molecules of insecticides and two of fungicides exceeded the concentrations set by Colombian regulations,

Universidad Nacional de Colombia, Faculty of Agricultural Sciences, Agronomy Department, Bogota (Colombia). ORCID López V., D.: 0000-0001-5880-4376; ORCID Sánchez, M.: 0000-0003-4398-5834; ORCID Darghan, A.E.: 00000001-5790-1684

2 Independent Consulter, Emeritus Researcher of Colciencias, Bogota (Colombia). ORCID Fischer, G.: 0000-0001-81010507

3 Universidad Nacional de Colombia, Faculty of Engineering, Department of Civil and Agricultural Engineering, Bogota (Colombia). ORCID Acuña, J.F.: 0000-0003-1668-5836

4 Corresponding author. gerfischer@gmail.com
\end{abstract}


but no significant differences were found between the two production systems. The calibration of equipment and applications must be improved in order to avoid over-concentration of pesticides, especially insecticides.

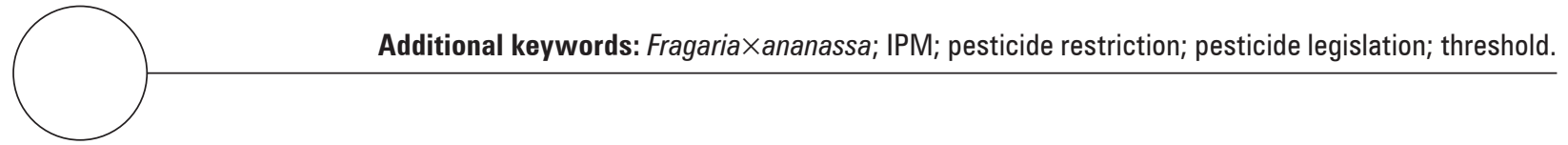

\section{RESUMEN}

Debido a la alta susceptibilidad del cultivo de fresa al ataque de plagas y enfermedades, una gran cantidad de plaguicidas son aplicados durante el ciclo de cultivo. El inadecuado uso de estas sustancias puede generar residuos en los productos agrícolas, los cuales, a través de la ingesta suponen un riesgo para la salud humana. El objetivo de este estudio fue determinar y comparar la residualidad de plaguicidas en frutos de fresa provenientes de dos sistemas productivos diferentes, distribuidos en las principales zonas productoras del departamento de Cundinamarca (Colombia). Se recolectaron ocho muestras de cultivos de fresa correspondientes a cuatro municipios productores (Guasca, Facatativá, Mosquera y Sibaté), para comparar los dos sistemas diferentes (producción convencional vs. producción basada en el Manejo Integrado de Plagas y Enfermedades, MIPE). En las muestras se examinaron las concentraciones de 394 moléculas mediante espectrometría líquida y gaseosa. Se utilizó la prueba exacta de Fisher para determinar la asociación entre el tipo de pesticida y el nivel de residuos en frutos, encontrando que más muestras de insecticidas excedieron el umbral de residualidad permitido que las de fungicidas. Se detectaron 22 moléculas diferentes para las muestras analizadas, con 37 eventos de detección, de los cuales ocho se reportaron en cultivos del sistema MIPE y 29 correspondieron a productores convencionales. Los resultados revelaron un total de nueve moléculas de insecticidas y dos de fungicidas en concentraciones excesivas para la normatividad colombiana, pero no se encontraron diferencias significativas entre los dos sistemas de producción. Existe la necesidad de mejorar la calibración de los equipos y de las aplicaciones para evitar las sobreconcentraciones de las pesticidas, especialmente de las insecticidas.

Palabras clave adicionales: Fragaria×ananassa; MIP; periodo de carencia; legislación sobre plaguicidas; umbral.

Received for publication: 12-09-2018 Accepted for publication: 29-03-2019

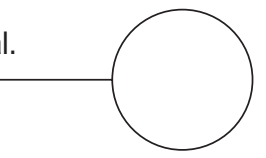

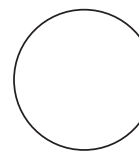

The Department of Cundinamarca is the largest strawberry producer in Colombia (Agronet, 2014), particularly the municipalities of Sibate, Choconta, Guasca, Alban and Facatativa, because of its favorable soils and climatic conditions (López-Valencia et al., 2018). The proximity of these municipalities to the city of Bogota favors the commercialization of this fruit; this department produces and distributes more than $60 \%$ of the strawberries consumed in this country (Flores and Mora, 2010).

The strawberry is susceptible to attacks from several pests and diseases, e.g. Phytonemus pallidus Banks (Acari: Tarsonemidae), Tetranychus urticae Koch (Acari: Tetranychidae), Frankliniella occidentalis Perg.
(Thysanoptera, Thripidae), Lygus sp., and Botrytis cinerea Pers., Colletotrichum acutatum (JH Simmonds), Phytophthora spp., Xanthomonas fragariae (Kennedy and King), Sphaerotheca pannosa (Wallr.) Lév., Verticillium sp., Rhizoctonia sp., Pythium sp., and Fusarium sp., both during the crop cycle and the post-harvest period (Maas, 1998). In order to manage this limitation, producers apply several pesticides (Wang et al., 2017). The intensive use of these substances in crops can contaminate the soil, air, and ground and surface water sources (Rodríguez et al., 2014), as well as generating collateral damage to beneficial organisms. In addition, pesticide residues in agricultural products pose a risk to human health (Nougadère et al., 2011). The Food and Agriculture Organization (FAO) and 
the World Health Organization (WHO) define pesticides as any substance or mixture of substances intended for the control of animal, plant or other species that are undesirably in production or postharvest processes (FAO, 1997).

Several studies have shown that agricultural products with pesticide residues that exceed a certain limit pose a potential risk to consumers. Adverse effects include blindness, liver diseases, increased cholesterol, neurological toxicity, alterations in the immune and reproductive system, lymphomas, prostate cancer, multiple myeloma, Parkinson's disease, infant mortality, and genetic disorders, among others (Chatterjee et al., 2013; Sinha et al., 2012; Gupta, 2006; Lozowicka, 2015). For the majority of the population, consumption is considered the principal potential route of exposure to pesticides (Nougadère et al., 2012; Cao et al., 2010; Panuwet et al., 2012).

As such, pesticide residues in agricultural products must be considered a public health issue that requires knowledge on and estimation of the active ingredients of these substances and the risk they pose to human health. As such, a health risk assessment should predict the likely effects of contaminants in humans during a given period (Wu et al., 2014). Some studies, including Jiang et al. (2005), Fianko et al. (2011) and Ezemonye et al. (2015), have estimated the potential risk to human health that could be derived from the consumption of food contaminated with pesticides.

Previous studies have shown that factors such as knowledge, perception of risk and perceived control on the use of pesticides are decisive for appropriate use (Flocks et al., 2007; Remoundou et al., 2013; Damalas and Khan, 2016). Some of these studies have explored knowledge on the use of pesticides among agricultural workers, finding serious shortcomings (Damalas and Khan, 2016; Houbraken et al., 2016). In Colombia, improper use of pesticides prevails partly because of an outdated regulatory framework, a high rate of poverty, and low rural education (Polanco et al., 2014).

In today's agriculture, the use of pesticides has several benefits (Majeed, 2018), so it is presumed that it will continue to be a fundamental part of crop management strategies. However, as mentioned by the previous author, there are alternative methods for the management of pests and diseases in crops that could be more expensive than conventional practices when the environmental and social costs of the use of conventional pesticides are not taken into account. Moreover, there is a growing demand for products free of chemical residues, which encourages research and development in alternative pest and disease management (Wang et al., 2017).

The IPM is defined as an integrated system that keeps damage from diseases and pests below the economically acceptable level (Ehler, 2006) and is also known as the "coordinated use of complementary methods to suppress pest, weeds and diseases", reducing environmental risks by monitoring and applying physical, biological, mechanical, cultural and chemical control for sustainable management of pests (Toth et al., 2018). The IPM includes practices for cultural, genetic, biological, mechanical and chemical control. It promotes economic and environmental sustainability, protects human health, and delays the development of resistance in pests and diseases with knowledge-intensive systems (Epstein and Zhang, 2014). Additionally, it has guidelines that encourage farmers to produce safe and innocuous fruits (Fernandes et al., 2012).

Previous studies have demonstrated the efficiency and efficacy of alternative methods of pest and disease management in the reduction of pesticide residues (Fernandes et al., 2012; Sundaram et al., 2018; Houbraken et al., 2016). Currently, the IPM is recognized as a mechanism that reduces risks related to the use of pesticides and ensures public health and environmental protection. IPM use is increasingly being promoted by the private sector, marketers and producers in response to consumer demand for healthy and safe food that is produced in a sustainable manner (Farfán, 2011; FAO, 2003).

For this study, a conventional production system was used that was not based on IPM concepts, maintaining practices that may be unsustainable without enough technical rigor or inadequate preharvest interval timing.

The objective of this study was to determine pesticide product residues in fresh strawberry fruits from two different production systems used on farms of the principal strawberry areas in the Cundinamarca Department. 


\section{MATERIALS AND METHODS}

\section{Production systems}

Strawberry fruits from the Cundinamarca municipalities of Sibate ( $4^{\circ} 29^{\prime} 27^{\prime \prime} \mathrm{N}$ and $74^{\circ} 15^{\prime} 34^{\prime \prime}$ W), Guasca $\left(4^{\circ} 51^{\prime} 57^{\prime \prime} \mathrm{N}\right.$ and $\left.73^{\circ} 52^{\prime} 38^{\prime \prime} \mathrm{W}\right)$, Facatativa (4'48'53"N and $\left.74^{\circ} 21^{\prime} 19^{\prime \prime} \mathrm{W}\right)$ and Mosquera $\left(4^{\circ} 42^{\prime} 28^{\prime \prime} \mathrm{N}\right.$ and $74^{\circ} 13^{\prime} 58^{\prime \prime}$ W) were analyzed since the Cundinamarca Department is the largest strawberry producer zone in Colombia. The conventional production systems were selected from the database of strawberry farmers in Cundinamarca found in the "Agroindustrial and Technology Corridor of Strawberry and Blackberry Project", along with practices for fertilization, pest and disease management, and harvest that were representative of each production zone. In these crops, monitoring and recording, including a semistructured interview, were used to identify common practices among strawberry farmers for the management of pests and diseases for 8 months, which corresponded to the period between planting and harvest peaks. The inspections focused on the following aspects: (1) equipment calibration, (2) application calibration, (3) reading and monitoring the directions on pesticide labels, and (4) registration of applications in the strawberry crop.

Production systems with IPM practices implemented concepts of the Good Agricultural Practices, based on monitoring and action thresholds for phytosanitary management. In the conventional systems, the strawberry farmers did not monitor or identify thresholds of action. Crops were selected with a preventive approach, that is, the timely and adequate implementation of agricultural practices. The chosen production systems were based on a profound knowledge on cultivation and its development, pests and diseases, biological controls and environmental conditions.

For crop protection, in the conventional strawberry systems, the control of the principal pests and diseases was carried out exclusively with the application of different fungicides, insecticides and acaricides, mainly: lambda-cyhalothrin, cypermethrin, azoxystrobin, difenoconazole, tebuconazole, pyrimethanil, benzimidazole, dimethoate, chlorfenapyr and chlorpyrifos. The two compared systems were delineated depending on the phytosanitary management, but the rest of the crop management was the same (nutrition, irrigation, plantation maintenance, and harvest, etc.).

In IPM based systems, the use of other forms of control such as cultural and biological methods was privileged, leaving chemical control as the last alternative for protection, using them on rare occasions. In addition, special importance was given to crop monitoring, through which the action thresholds were implemented.

B. cinerea is one of the most limiting pathogens in strawberry crops, and Trichoderma harzianum Rifai and the cultural practice of removing and destroying infected material were used for management, as in IPM practices. It is important to note that, within the IPM system, an adequate fertilization plan with an appropriate amount of $\mathrm{Ca}$ and beneficial nutrients favored a low incidence and severity of pests and diseases in the crop.

The management of pests, such as the mite T. urticae, was carried out with the release of the predator Amblyseius californicus (syn. Neoseiulus californicus McGregor (Acari: Phytoseiidae)). This intervention, in the case of the Guasca crop, drastically reduced the amount of insecticides-acaricides applied to the crop and, in the case of Sibate, completely eliminated the application of these products.

\section{Strawberry samples}

The eight strawberry samples used in the residue analysis consisted of fruits at the harvest point of different varieties, qualities and sizes, all representatives from their respective area. Each sample consisted of approximately $1 \mathrm{~kg}$ of fruit. The strawberry samples were not treated or handled in a special way or different from the conventional harvesting practices.

The origin of each sample was as follows: (1) two samples from the municipality of Sibate, each one from a different production system (conventional and IPM); (2) two samples from the municipality of Guasca, in this case one with IPM and the other a set of fruits from different plots, all with conventional management; (3) two samples from the municipality of Mosquera, one with IPM and the other was obtained from a local fruit market (in this case the fruits had been exposed to a shelf-life of $1 \mathrm{~d}$ ); (4) two samples from the municipality of Facatativa, one represented the IPM and the other conventional management. 


\section{Chemical analysis}

Each sample was placed in hermetically sealed bags, at temperatures between 2 and $4^{\circ} \mathrm{C}$ and taken to the laboratory on the same day of harvest. Once delivered to the laboratory, the samples were stored to prevent changes in their properties. The analysis was performed by the company Primoris Colombia SAS, Bogota, Colombia (ISO17025 and certificate 057-Test).

The presence and concentration of 394 pesticides (most used in agriculture, according to the codex alimentarius bases) were evaluated with gas chromatography coupled to a mass spectrophotometer (GC/ $\mathrm{MS} / \mathrm{MS}$ ) using helium as a carrier gas and a capillary column. The instruments used included a chromatograph with an Agilent self-sampler (Santa Clara, CA) and a Waters spectrophotometer (Milford, MA), and the standards used were prepared from pure pesticides. Additionally, liquid chromatography coupled to a mass spectrophotometer (LC/MS/MS) was carried out using acetonitrile and water as the mobile phase and a C18 column. A chromatograph with selfsampler and Waters spectrophotometer were used, and the standards used were prepared from pure pesticides.

\section{Statistical analysis}

The comparison of the results was made by counting the detected events, analyzed according to Fisher's exact test (two tails), forming a two-way contingency table with the pesticide type and residues in excess or at normal values since the data were associated with the counts found in the samples with the pair of variables crossed in the table. A 90\% confidence level was used to test the independence hypothesis using the SAS 9.2® software (Stokes et al, 2000).

The criterion of acceptance of the maximum limits of the residue in the data analysis was based on the European Community regulations (EC, 2017) since its database is extensive, and the maximum residue limits (MRLs) for strawberries are clear and specific.

\section{RESULTS}

\section{Use of pesticides}

Of the 24 strawberry farmers who applied conventional pest and disease management practices in the representative areas of Cundinamarca, as observed between July of 2016 and February of 2017, most of the farmers were men (79\%).

The information on the knowledge and use of pesticides was analyzed without taking into account the location of the production system (Tab. 1). Most of the observed strawberry producers of the project performed their applications with the use of stationary pumps $(96 \%)$. The preparation of the mixtures was done manually, without the use of appropriate safety equipment. In most cases, the calibration of the equipment and the calibration of the application were not performed, 87 and $100 \%$, respectively, which makes it difficult to dose these pesticides.

For the pesticide labels, it was found that $83 \%$ of the producers did not read or follow directions, and only $8 \%$ always did it before the application. Moreover, $37 \%$ of farmers did not have a record of the products applied to the crop, and most of them (46\%) recorded them sometimes.

Table 1. Conventional practices in the use of pesticides of 24 interviewed farmers.

\begin{tabular}{|l|c|c|}
\hline Variable & Observation & Count \\
\hline \multirow{4}{*}{$\begin{array}{l}\text { Calibration of the } \\
\text { equipment }\end{array}$} & Always & 0 \\
\cline { 2 - 3 } & Most of the time & 2 \\
\cline { 2 - 3 } Calibration of the & Rarely & 1 \\
\hline \multirow{3}{*}{\begin{tabular}{l} 
application \\
\cline { 2 - 3 }
\end{tabular}} & Never & 21 \\
\hline \multirow{3}{*}{ Reading labels } & Always & 0 \\
\cline { 2 - 3 } & Rost of the time & 0 \\
\cline { 2 - 3 } & Never & 0 \\
\cline { 2 - 3 } & Always & 24 \\
\cline { 2 - 3 } & Most of the time & 2 \\
\hline \multirow{3}{*}{ Record of application } & Rarely & 2 \\
\cline { 2 - 3 } & Never & 20 \\
\cline { 2 - 3 } & Always & 3 \\
\cline { 2 - 3 } & Most of the time & 1 \\
\hline & Rarely & 11 \\
\hline
\end{tabular}

\section{Analysis of the samples}

Of the 394 evaluated active ingredients, only 22 were present in the strawberry fruits in all evaluated locations (Tab. 2). 
The municipalities with the highest number of residues of pesticides in the strawberry fruits reported were Facatativa (13), Guasca (11) and Sibate (10). Of the substances found by municipality, the pesticides in the conventional crops corresponded to Facatativa (53\%), Sibate (90\%), Guasca (91\%) and Mosquera (100\%). The most toxic substances (Category I and II) listed by municipalities were: Sibate (7 compounds), Facatativa (3 compounds), Guasca (3 compounds) and Mosquera (2 compounds). The substances most frequently found in the analyzed samples were fungicides, with a total of 22 reports in eight analyses, and only 15 reports of insecticides-acaricides were found (Tab. 2).

Of the total of 12 active ingredients belonging to insecticides-acaricides found in the strawberry fruits of all municipalities, $42 \%$ were organophosphates, $17 \%$ pyrethroids, $8 \%$ neonicotinoids, $8 \%$ carboxamide (hexythiazox), 8\% propargite, $8 \%$ pyrroles and $8 \%$ tetronic and tetramic acid derivatives.

In the case of fungicides, of the 10 active ingredients found in the strawberry fruits from all municipalities, $30 \%$ were inhibitors of demethylation, $20 \%$ inhibitors of the kinase, $20 \%$ methyl benzimidazole carbamates, $10 \%$ phenylamides, $10 \%$ carboxamides and $10 \%$ aniline-pyrimidines. The most common modes of action were inhibition of membrane biosynthesis and transpiration inhibition.

\section{Comparison between production systems}

Results from the pesticide residues tested on the strawberry fruits showed differences between the conventional production systems and the systems with IPM practices, but they could not be proven

Table 2. Residues of pesticides detected in strawberry fruits from all locations (Cundinamarca-Colombia, between July, 2016 and February, 2017).

\begin{tabular}{|c|c|c|c|c|}
\hline Active ingredient & Commercial name & Toxicity category & Classification & Action mode ${ }^{1}$ \\
\hline Methamidophos & Nadir $^{\circledR} 600$ SL & I & Insecticide/acaricide & 1B \\
\hline Chlorfenapyr & Sunfire ${ }^{\circledR} 24$ SC & $\|$ & Insecticide & 13 \\
\hline Trichlorfon & Profitox 80 SP & $\|$ & Insecticide & $1 \mathrm{~B}$ \\
\hline Thiamethoxam & Enge $0^{\circledR}$ & $\|$ & Insecticide & $4 \mathrm{~A}$ \\
\hline Bifenthrin & Brigada $^{\circledR} 100$ EC & $\|$ & Insecticide/acaricide & $3 \mathrm{~A}$ \\
\hline Cyhalothrin & Engeo ${ }^{\circledR}$ & $\|$ & Insecticide/acaricide & $3 \mathrm{~A}$ \\
\hline Dimethoate & Roxion $^{\circledR} 40$ EC & $\|$ & Insecticide/acaricide & $1 \mathrm{~B}$ \\
\hline Profenofos & Fulminator $600 \mathrm{EC}$ & $\|$ & Insecticide/acaricide & $1 \mathrm{~B}$ \\
\hline Chlorpyrifos & Lorsban $^{\mathrm{TM}} 4 \mathrm{EC}$ & $\|$ & Insecticide/acaricide & $1 \mathrm{~B}$ \\
\hline Fluopyram & Luna $^{\circledR}$ Tranquility & $\|$ & Fungicide & $\mathrm{C} 2$ \\
\hline Azoxystrobin & Amistar ${ }^{\circledR}$ TOP CS & $\|$ & Fungicide & $\mathrm{C3}$ \\
\hline Pyrimethanil & Luna ${ }^{\circledR}$ Tranquility & $\|$ & Fungicide & D1 \\
\hline Spiromesifen & Oberon ${ }^{\circledR}$ SC 240 & III & Insecticide/acaricide & 23 \\
\hline Tebuconazole & Nativo ${ }^{\circledR}$ SC & III & Fungicide/bactericide & G1 \\
\hline Carbendazim & Carbendazim 500 & III & Fungicide & $\mathrm{B} 1$ \\
\hline Epoxiconazole & Opera ${ }^{\circledR}$ SC & III & Fungicide & G1 \\
\hline Thiabendazole & Mertect $^{\circledR} 500$ SC & III & Fungicide & $\mathrm{B} 1$ \\
\hline Metalaxyl & Ridomil $^{\circledR}$ Gold MZ 68 WP & III & Fungicide & A1 \\
\hline Pyraclostrobin & Opera $^{\circledR}$ SC & III & Fungicide & $\mathrm{C} 3$ \\
\hline Difenoconazole & Amistar $^{\circledR}$ TOP CS & III (II O III) & Fungicide & G1 \\
\hline Hexytiazox & Lathix 54 EC & III & Acaricide & $10 \mathrm{~A}$ \\
\hline Propargite & Omite ${ }^{\circledR}$ 6EC & III & Acaricide & $12 \mathrm{C}$ \\
\hline
\end{tabular}

'Reference code of the FRAC and IRAC. Organophosphates (1B), pyrethroids and pyrethrins (3A), neonicotinoids (4A), clofentezine, diflovidazin and hexythiazox (10A), propargite (12C), chlorfenapyr, dnoc and sulfluramid (13), tetronic and tetramic acid derivatives (23), RNA polymerase I (A1), B-tubulin assembly in mitosis (B1), inhibition of complex II: succinate-dehydrogenase (C2), inhibition of complex III cytochrome ubiquinol oxidase (C3), methionine biosynthesis (D1), C14- demethylase in sterol biosynthesis (G1). 
statistically. The lowest amount of pesticide residues was found in the crops with IPM in the installed demonstration plots of the project: Sibate 1 substance, Mosquera 0, Guasca 1, and Facatativa 6 (Tab. $3)$. On the other hand, the conventional systems showed the following amounts: Sibate 9 substances, Mosquera 3, Guasca 10, and Facatativa 7 (Tab. 4). Of the 37 total appearances of pesticide traces, only 8 corresponded to traces in crops with IPM (Tab. 3), that is, only $21.6 \%$. In the fruits from the Mosquera crops, no pesticide residue was detected.

\section{Table 3. Residues of pesticides detected in crops with IPM practices.}

\begin{tabular}{|l|c|c|}
\hline Municipalities & Active ingredient & $\begin{array}{c}\text { Concentration } \\
\left(\mathbf{m g ~ k g}^{-1}\right)\end{array}$ \\
\hline Sibate & Pyrimethanil & 0.048 \\
\hline Guasca & Thiabendazole & 0.027 \\
\hline \multirow{5}{*}{ Facatativa } & Pyraclostrobin & 0.050 \\
\cline { 2 - 3 } & Carbendazim & 0.026 \\
\cline { 2 - 3 } & Epoxiconazole & 0.018 \\
\cline { 2 - 3 } & Fluopyram & 0.066 \\
\cline { 2 - 3 } & Pyrimethanil & 0.300 \\
\cline { 2 - 3 } & Trichlorfon & 0.150 \\
\hline
\end{tabular}

In the fungicide residues detected in the strawberry fruits, the active ingredient pyrimethanil was found in the IPM crops in Sibate and Facatativa. In the case of Facatativa, because of the greater number of residues of all types of pesticides, it was possible to create a two-way contingency table with the categories associated with the production system and the level of residues in the fruits.

The Fisher's exact test was used in order to determine the relationships between the qualitative variables associated with the pesticide type and residues in excess or at normal values (Tab. 5). It was found that there was a relationship of statistical dependence between the level of toxicity registered and the pesticide type applied, with a much higher amount exceeding the threshold for insecticides (9) than for fungicides (2).

Similarly, the use of different pesticides among the municipalities was evidenced since $48 \%$ of the 29 active ingredients found in the fruits were not detected in the others, and the remaining $52 \%$ were detected only in two locations at the same time. In Sibate, the conventional crops showed excessively high concentrations of cyhalothrin and carbendazim according to the Colombian Maximum Residue Levels (MRLs) (Arias et al., 2014).

\section{Table 4. Residues of pesticides detected in fruits from the conventional crop system.}

\begin{tabular}{|c|c|c|}
\hline Farmer & Active ingredient & Concentration $\left(\mathrm{mg} \mathrm{kg}^{-1}\right)$ \\
\hline \multirow{9}{*}{ Sibate } & Cyhalothrin & 0.350 \\
\hline & Profenofos & 0.014 \\
\hline & Azoxystrobin & 0.034 \\
\hline & Carbendazim & 0.160 \\
\hline & Methamidophos & 0.150 \\
\hline & Pyrimethanil & 0.097 \\
\hline & Tebuconazole & 0.120 \\
\hline & Thiamethoxam & 0.220 \\
\hline & Trichlorfon & 0.039 \\
\hline \multirow{10}{*}{ Guasca } & Chlorpyrifos & 0.040 \\
\hline & Propargite & 0.061 \\
\hline & Pyraclostrobin & 0.080 \\
\hline & Spiromesifen & 0.240 \\
\hline & Carbendazim & 0.020 \\
\hline & Epoxiconazole & 0.048 \\
\hline & Hexytiazox & 0.070 \\
\hline & Metalaxyl & 0.010 \\
\hline & Methamidophos & 1.700 \\
\hline & Dimethoate & 0.290 \\
\hline \multirow{7}{*}{ Facatativa } & Bifenthrin & 0.030 \\
\hline & Pyraclostrobin & 0.030 \\
\hline & Carbendazim & 0.060 \\
\hline & Epoxiconazole & 0.010 \\
\hline & Fluopyram & 0.040 \\
\hline & Pyrimethanil & 0.130 \\
\hline & Trichlorfon & 0.670 \\
\hline \multirow{3}{*}{ Mosquera } & Chlorfenapyr & 0.086 \\
\hline & Azoxystrobin & 0.130 \\
\hline & Difenoconazole & 0.069 \\
\hline
\end{tabular}

Table 5. Bivariate distribution of the sample count by type of pesticide and level of toxicity with results of Fisher's exact test.

\begin{tabular}{|l|c|c|}
\hline \multirow{2}{*}{ Toxicity } & \multicolumn{2}{|c|}{ Pesticide } \\
\cline { 2 - 3 } & Insecticide & Fungicide \\
\hline In excess & 9 & 2 \\
\hline Acceptable & 6 & 22 \\
\hline Fisher's exact test $(P$ value $)$ & & 0.0008 \\
\hline Contingency coefficient & 0.4877 \\
\hline
\end{tabular}




\section{DISCUSSION}

Knowledge on and adequate use of pesticides by producers is of great importance since they are an essential part of strategies that seek to reduce environmental risks and damage to human health (Houbraken et al., 2016). Trained farmers can read and interpret the pesticide labels and perform the applications correctly; in contrast, poorly trained farmers have greater difficulties performing appropriate integrated crop management (Ibitayo, 2006; Damalas and Eleftherohorinos, 2011).

The lack of application calibration makes it possible to identify problems associated with the application of the recommended amount of pesticide according to technicians and labels. This also makes it impossible to ensure the quantity of water used or the effectiveness of the application (ICA, 2009). Bastidas et al. (2013) reported similar results, in which the presence of pesticide residues in passiflora crops was mainly due to the lack of implementation of Good Agricultural Practices (GAP). As indicated by Nausa (2005), strawberry farmers in Cundinamarca mostly do not receive appropriate technical assistance, so the criterion for the application of pesticides is their own experience, which is influenced by neighbors, technicians from agrochemical companies and agricultural store recommendations.

The proper use of a pesticide depends directly on the information available on its label. Therefore, a label on the container is essential and sometimes the only element available for farmers to obtain this information (PSU, 2005). Thus, the limited reading and interpretation of pesticide labels and the limited records of applications reported in this study negatively affect the environment and food safety of the harvested fruits (Pierre and Betancourt, 2007). As reported by Damalas and Khan (2016) and Guerrero (2003), the main causes of the levels of pesticide residues found in excess in fruit and vegetables include the inadequate use of doses, application frequencies and omission of the recommended time lapse between applications and the harvest.

Several studies have reported the presence of organophosphate residues in strawberry fruits. Bélanger et al. (1990) reported dimethoate residues in strawberry fruits up to $18 \mathrm{~d}$ after application. Bempah et al. (2011) found traces of methamidophos and dimethoate, and Guerrero (2003) recorded traces of chlorpyrifos, profenofos and dimethoate.
According to Nausa (2005), the application of commercial products such as: Lorsban $₫$, Trapper ${ }^{\circledR}$, Tamaron ${ }^{\circledR}$ and Monitor ${ }^{\circledR}$, is common in strawberry crops in Cundinamarca. The active ingredients in these products are organophosphates (chlorpyrifos and methamidophos), which was the main chemical group of insecticides/acaricides with the highest number of residues found during our experiment.

Currently, in Colombia, there is no registered product for strawberries with the active ingredient cyhalothrin. However, there are reports of its use in this crop, with a residue detection period of more than $23 \mathrm{~d}$ (Kovacova et al., 2013). The use of cyhalothrin in crops with the IPM is not recommended as it has adverse effects in non-target organisms (Kovacova et al., 2013). Cyhalotrin residuality tests conducted by FAO (n.d.) confirmed that, after $3 \mathrm{~d}$, the maximum concentration of this active ingredient did not exceed $0.09 \mathrm{mg} \mathrm{kg}^{-1}$. In our results, a cyhalothrin concentration of $0.350 \mathrm{mg} \mathrm{kg}^{-1}$ demonstrated an over-application of this pesticide. Cyhalothrin is slightly toxic in terrestrial organisms and very toxic in aquatic organisms (He et al., 2008). Fetoui et al. (2009) concluded that cyhalothrin can induce oxidative stress and modification of biochemical parameters and histological aspects in the liver of rats.

Toth et al. (2018) determined that crops with IPM practices had lower amounts of pesticide residues than with conventional systems. However, these authors clarified that no option is completely free of residues. For this study, the IPM approach implied a set of cultural, biological and chemical strategies, as well as the selection of resistant varieties that complement each other when keeping pests and diseases at levels lower than those that cause economic damage to crops (INTA, 2013).

Under IPM practices, if the use of pesticides is required, they should be applied at the appropriate time and place, limiting applications to specific points where possible (Zhang et al., 2015). Based on the reports of Epstein and Zhang (2014), the IPM approach does not always reduce the use of pesticides, but can direct it to the areas with the greatest pest problems. In this way, the amount of pesticide used per unit area is reduced, along with the risk of pesticide residues in harvested foods; likewise, good implementation and the consequent efficiency in the use of pesticides can contribute to the reduction of these substances over time. 


\section{CONCLUSIONS}

The results show that there are active ingredient residues of pesticides that exceed the maximum residue limits (MRLs) of Colombia in the different strawberry cultivation systems in Cundinamarca. The presence of residues was shown to be mainly related to the lack of implementation of good agricultural practices by farmers, especially for application and equipment calibration. When the calibration of equipment and applications is not performed by farmers, correct dosing of pesticides is very difficult.

The results indicate the need for frequent monitoring using pesticide residue analysis to ensure fruit safety, e.g. by government organizations, both for exportation and national consumption. The results highlight the urgency of developing and implementing integrated pest control packages in strawberry crops and raising awareness of the good agricultural practices in the use of pesticides.

\section{ACKNOWLEDGMENTS}

The authors express their gratitude to the institutions that are part of Agreement 2 of the Corredor Tecnológico Agroindustrial alliance for financing the Subproject "Research and technological development in the production systems of fruits (strawberry and blackberry) in the representative producing areas of Cundinamarca", as well as to the farmers who are beneficiaries of this subproject for providing the product and allowing the monitoring of the variables of pest and disease management in their crops.

Conflict of interests: this manuscript was prepared and reviewed with the participation of the authors, who declare that there exists no conflict of interest that puts the validity of the presented results at risk.

\section{BIBLIOGRAPHIC REFERENCES}

Agronet. 2014. Estadísticas: Comparativo de área, producción, rendimiento y participación departamental por cultivo. In: http://www.agronet.gov.co/estadistica/Paginas/default.aspx; consulted: May, 2017.

Arias, L.A., C.R. Bojacá, D.A. Ahumada, and E. Schrevens. 2014. Monitoring of pesticide residues in tomato marketed in Bogota, Colombia. Food Control 35(1), 213217. Doi: 10.1016/j.foodcont.2013.06.046

Bastidas, D.A., J.A. Guerrero, and K. Wyckhuys. 2013. Residuos de plaguicidas en cultivos de pasifloras en regiones de alta producción en Colombia. Rev. Colomb. Quím. 42(2), 39-47.

Bélanger, A., C. Vicent, and D. Oliveira. 1990. A field study on residues of four insecticides used in strawberry protection. J. Environ. Sci. Health 25(5), 615-625. Doi: 10.1080/03601239009372709

Bempah, C.K., A. Donkor, P.O. Yeboah, B. Dubey, and P. Osei-Fosu. 2011. A preliminary assessment of consumer's exposure to organochlorine pesticides in fruits and vegetables and the potential health risk in Accra Metropolis, Ghana. Food Chem. 128(4), 1058-1065. Doi: 10.1016/j.foodchem.2011.04.013

Cao, Z., T.J. Shafer, and T.F. Murray. 2010. Mechanisms of pyrethroid insecticide-induced stimulation of calcium influx in neocortical neurons. J. Pharmacol. Exp. Ther. 336(1), 197-205. Doi: 10.1124/jpet.110.171850

Chatterjee, S., P. Basak, M. Chaklader, P. Das, J.A. Pereira, S. Chaudhuri, and S. Law. 2013. Pesticide induced marrow toxicity and effects on marrow cell population and on hematopoietic stroma. Exp. Toxicol. Pathol. 65(3). 287-295. Doi: 10.1016/j.etp.2011.09.002

Damalas, C.A. and I.G. Eleftherohorinos. 2011. Pesticide exposure, safety issues, and risk assessment indicators. Int. J. Environ. Res. Public Health 8(5), 1402-1419. Doi: 10.3390/ijerph8051402

Damalas, C.A. and M. Khan. 2016. Farmers' attitudes towards pesticide labels: implications for personal and environmental safety. Int. J. Pest Manag. 62(4), 319325. Doi: 10.1080/09670874.2016.1195027

EC, European Community. 2017. EU - Pesticides database. In: http://ec.europa.eu/food/plant/pesticides/eupesticidesdatabase/public/? event = activesubstance.selection\&language $=E N$; consulted: June, 2017.

Ehler, L.E. 2006. Integrated pest management (IPM): definition, historical development and implementation, and the other IPM. J. Pest. Manag. Sci. 62(9), 787-789. Doi: $10.1002 / p s .1247$

Epstein, L. and M. Zhang. 2014. The impact of Integrated Pest Management programs on pesticide use in California, USA. pp. 173-200. In: Peshin, E. and D. Pimentel (eds.). Integrated pest management. Springer, Dordrecht, The Netherlands. Doi: 10.1007/978-94-007-7802-3_7

Ezemonye, L., O. Ogbeide, and I. Tongo. 2015. Distribution and ecological risk assessment of pesticide residues in surface water, sediment and fish from Ogbesse River, Edo State, Nigeria. J. Environ. Chem. Ecotoxicol. 7(2), 20-30.

FAO (n.d.). Cyhalotrin. In: http://www.fao.org/fileadmin/ templates/agphome/documents/Pests_Pesticides/ JMPR/Report08/Cyhalothrin.pdf; consulted: June, 2017.

FAO. 1997. Comisión del Codex Alimentarius: manual de procedimiento. $10^{\text {th }} \mathrm{ed}$. Seccion I, Definiciones para los fines del Codex Alimentarius. FAO, Rome. 
FAO. 2003. Report of the expert consultation on a Good Agricultural Practices (GAP). Agriculture Department Report. FAO, Rome.

Farfán, F.V. 2011. Las buenas prácticas agrícolas en la caficultura. pp. 1-2. In: Sistemas de producción de café en Colombia. Ed. Cenicafé, Chinchina, Colombia.

Fernandes, V., V. Domingues, N. Mateus, and C. Delerue. 2012. Pesticide residues in Portuguese strawberries grown in 2009-2010 using integrated pest management and organic farming. Environ. Sci. Pollut. Res. 19, 4184-4192. Doi: 10.1007/s11356-012-0934-9

Fetoui, H., E.M. Garoui, and N. Zeghal. 2009. Lambda-cyhalothrin-induced biochemical and histopathological changes in the liver of rats: Ameliorative effect of ascorbic acid. Exp. Toxicol. Pathol. 61(3), 189-196. Doi: 10.1016/j.etp.2008.08.002

Fianko, J.R., A. Donkor, S.T. Lowor, and P.O. Yeboah. 2011. Agrochemicals and the Ghanaian environment, a review. J. Environ. Prot. 2, 221-230. Doi: 10.4236/ jep.2011.23026

Flocks, J., P. Monaghan, S. Albrecht, and A. Bahena. 2007. Florida farmworkers' perceptions and lay knowledge of occupational pesticides. J. Community Health 32(3), 181-94. Doi: 10.1007/s10900-006-9040-6

Flores, R. and R. Mora. 2010. Fresa (Fragaria ×ananassa) producción, manejo y poscosecha. Produmedios, Bogota, Colombia.

Guerrero, J. 2003. Estudio de residuos de plaguicidas en frutas y hortalizas en áreas específicas de Colombia. Agron. Colomb. 21(3), 198-209.

Gupta, R.C. 2006. Toxicology of organophosphate and carbamate compound. Elsevier Academic Press, Amsterdam, The Netherlands.

He, L.-M., J. Troiano, A. Wang, and K. Goh. 2008. Environmental chemistry, ecotoxicity, and fate of lambda-cyhalothrin. pp. 71-91. In: Whitacre, D.M. (ed.). Reviews of environmental contamination and toxicology. Vol. 195. Springer, New York. Doi: 10.1007/978-0-387-77030-7_3

Houbraken, M., I. Bauweraerts, D. Fevery, M.C. Van Labeke, and P. Spanoghe. 2016. Pesticide knowledge and practice among horticultural workers in the Lâm Đồng region, Vietnam: a case study of chrysanthemum and strawberries. Sci. Total Environ. 550, 1001-1009. Doi: 10.1016/j.scitotenv.2016.01.183

Ibitayo, O.O. 2006. Egyptian farmers' attitudes and behaviors regarding agricultural pesticides: implications for pesticide risk communication. Risk Anal. 26, 989995. Doi: 10.1111/j.1539-6924.2006.00794.x

ICA, Instituto Colombiano Agropecuario. 2009. Manual temático del facilitador en Buenas Prácticas Agrícolas. Instituto Colombiano Agropecuario, Bogota, Colombia.
INTA, Instituto Nacional de Tecnologías Agropecuaria. 2013. Manejo integrado de plagas y enfermedades. In: http://inta.gob.ar/sites/default/files/script-tmp-inta_-_manejo_integrado_de_plagas__hase_2013_norma_-a.pdf; consulted: Juñe, 2017.

Jiang, Q.T., T.K.M. Lee, K. Chen, H.L. Wong, J.S. Zheng, J.P. Giesy, K.K.W. Lo, N. Yamashita, and P.K.S. Lam. 2005. Human health risk assessment of organochlorines associated with fish consumption in a coastal city in China. Environ. Pollut. 136, 155-165. Doi: 10.1016/j. envpol.2004.09.028

Kovacova, J., V. Hrbek, J. Kloutvorova, V. Kocourek, L. Drabova, and J. Hajslova. 2013. Assessment of pesticide residues in strawberries grown under various treatment regimes. Food Addit. Contam. Part A 30(12), 2123-2135. Doi: 10.1080/19440049.2013.850537

López-Valencia, D., M. Sánchez-Gómez, J.F. Acuña-Caita, and G. Fischer. 2018. Propiedades fisicoquímicas de siete variedades destacadas de fresa (Fragaria $\mathrm{x}$ ananassa Duch.) cultivadas en Cundinamarca (Colombia), durante su maduración. Corpoica Cienc. Tecnol. Agropec. 19(1), 147-162. Doi: 10.21930/rcta. vol19_num1_art:528

Lozowicka, B. 2015. Health risk for children and adults consuming apples with pesticide residue. Sci. Total Environ. 502(1), 184-198. Doi: 10.1016/j. scitotenv.2014.09.026

Maas, J.L. 1998. Compendium of strawberry diseases. APS Press, St. Paul, MN. Doi: 10.1094/9780890546178

Majeed, A. 2018. Application of agrochemicals in agriculture: benefits, risks and responsibility of stakeholders. J. Food Sci. Toxicol. 2, 1-2.

Nausa, O.F. 2005. Diagnóstico de patrones de uso y manejo de plaguicidas en frutales de clima frío en el departamento de Cundinamarca. Undergraduate thesis. Facultad de Agronomía, Universidad Nacional de Colombia, Bogota, Colombia.

Nougadère, A., J.C. Reninger, J.L. Volatier, and J.C. Leblanc. 2011. Chronic dietary risk characterization for pesticide residues: A ranking and scoring method integrating agricultural uses and food contamination data. Food Chem. Toxicol. 49, 1484-1510. Doi: 10.1016/j. fct.2011.03.024

Nougadère, A., V. Sirot, A. Kadar, A. Fastier, E. Truchot, C. Vergnet, F. Hommet, J. Baylé, P. Gros, and J. Leblanc. 2012. Total diet study on pesticide residues in France: levels in food as consumed and chronic dietary risk to consumers. Environ Int. 45, 135-150. Doi: 10.1016/j. envint.2012.02.001

Panuwet, P., W. Siriwong, T. Prapamontol, P.B. Ryan, N. Fiedler, M.G. Robson, and D.B. Barr. 2012. Agricultural pesticide management in Thailand: situation and population health risk. Environ. Sci. Policy 17, 72-81. Doi: 10.1016/j.envsci.2011.12.005 
Pierre, F. and P. Betancourt. 2007. Residuos de plaguicidas organoclorados y organofosforados en el cultivo de cebolla en la depresión de Quíbor, Venezuela. Bioagro 19(2), 69-78.

Polanco, Y., J.C. Salazar, and B. Curbow. 2014. A quantitative analysis of Colombian campesinos' use of pesticides: perceived control and confidence in this use. Rev. Fac. Nac. Salud Pública 32(3), 373-382.

PSU, Pennsylvania State University. 2005. Cómo leer la etiqueta de un pesticida. In: http://extension.psu.edu/ pests/pesticide-education/applicators/fact-sheets/ consumer/uo226; consulted: June, 2017.

Remoundou, K., M. Brennan, A. Hart, and L. Frewer. 2013. Pesticide risk perceptions, knowledge, and attitudes of operators, workers, and residents: a review of the literature. Human Ecol. Risk Assesm. Int. J. 20(4), 11131138. Doi: 10.1080/10807039.2013.799405

Rodríguez, A.M., S. Suarez, and D. Palacio. 2014. Effects of pesticides on health and the environment. Rev. Cub. Hig. Epidemiol. 52(3), 372-387.

Sinha, S.N., M. Rao, and K. Vasudev. 2012. Distribution of pesticides in different commonly used vegetables from Hyderabad, India. Food Res. Int. 45, 161-169. Doi: 10.1016/j.foodres.2011.09.028
Stokes, M.E., C.S. Davis, and G.G. Koch, 2000. Categorical data analysis using the SAS® system. SAS Institute Inc., Cary, NC.

Sundaram, D., C. Partheeban, and S. Srividhya. 2018. Assessment and management of pesticide residual toxicity in grapes and strawberry. Int. J. Chem. Studies $6(2), 1195-1197$.

Toth, I.K., A.K. Less, R. Neilson, J. Brierley, and D. Bienkowski. 2018. Research on Integrated Pest Management (IPM) for potato. pp. 187-192. In: The Dundee Conference. The Association for Crop Protection in Northern Britain, Dundee, Scotland.

Wang, J., W. Cheng, J. Wu, and M. Ji. 2017. Goals and key technology of fertilizer-pesticide "Double Reduction" and synergism for greenhouse strawberry. Agric. Sci. Technol. 18(11), 2113-2122.

Wu, C., Y.M. Lou, T. Gui, and Y.J. Huang. 2014. Concentrations and potencial health hazard of organochlorine pesticides in shallow groundwater of Taihu Lake region, China. Sci. Total Environ. 470, 1047-1055. Doi: 10.1016/j.scitotenv.2013.10.056

Zhang, M., M. Zeiss, and S. Geng. 2015. Agricultural pesticide use and food safety: California's model. J. Integr. Agric. 14(11), 2340-2357. Doi: 10.1016/ S2095-3119(15)61126-1 